\section{The politics of a new Mental Health Act}

\author{
JOANNA MONCRIEFF
}

Recent proposals for reforming the Mental Health Act show that the Government is keen to increase restrictions on current psychiatric patients and to extend the boundaries of psychiatric legislation. The proposals contained in the new Mental Health Bill (Department of Health, 2002) seem destined to make it easier to be subject to compulsory powers and more difficult to be rid of them.

These proposals seem to indicate that the Government is motivated to increase social control through the agency of psychiatry. I will argue that although the state relinquished its historical role in incarceration of the mad to the medical profession in 1959 , it is currently trying to re-establish control over the process by enacting some of the most repressive psychiatric legislation of recent times.

\section{RECENT DEVELOPMENTS}

Informally, the impetus to reform dates back over a decade to increasing government and media concern about the consequences of deinstitutionalisation. The perception was that the closing of the old asylums meant that people with mental illnesses were inadequately contained and were putting the community at risk. The new Labour Government continued to express these concerns and instructed the Richardson Committee, set up to make formal recommendations for new legislation, to consider how the 'scope of legislation might be extended beyond the hospital to cover care and treatment provided in community settings' (Department of Health $1999 a$, p. 7).

Shortly after the Richardson Committee was set up the Home Office, in direct response to the case of Michael Stone, announced its concern to use psychiatric legislation to ensure the confinement of people with 'dangerous severe personality disorders'. This term was coined for the first time in the Home Office report (Joint Home Office \& Department of Health Working Group, 1999).

The subsequent White Paper was clearly designed to incorporate both agendas. It also clearly stated the Government's objectives with the statement that 'concerns of risk will always take precedence' (Department of Health/Home Office, 2000).

\section{IMPLICATIONS OF THE MENTAL HEALTH BILL}

The Mental Health Bill published in July 2002 outlines a detailed framework for new legislation. The Appendix lists some of the main ways in which it differs from the Mental Health Act 1983. The general effect of the proposals is to increase the circumstances in which someone might be assessed and subjected to compulsory detention or treatment and to reduce avenues for discharge. It will be particularly difficult to argue for discharge from a non-resident or community order. There has been some debate about whether the new act will allow the preventive detention of people considered to be dangerous. Some have argued that the treatability of all conditions remains relevant because 'appropriate medical treatment' must be available (Sugarman, 2002). However, the existence of a separate clause for people who pose a risk seems clearly to imply that there is no requirement or expectation, in these cases, that 'treatment' will benefit the patient.

Extension of compulsory powers into community settings inevitably means that use of the Mental Health Act will increase above current levels. Community orders will entail that the act is applied to people with lower levels of dysfunction than when it was applied only to people who required admission to hospital. The abolition of guardianship is an indication of the reorientation of legislation away from a concern with how to provide care towards a more exclusive focus on 'treatment'.

The Mental Health Bill reduces the autonomy of psychiatrists in decisions about when to apply compulsion and what form treatment might take. It is not clear to what extent tribunals will engage in the details of treatment plans, but they will have the power to force doctors to 'treat' patients when the doctor feels that this is inappropriate. It seems therefore that the tribunal system has been designed to increase the use of compulsory powers rather than to act in patients' interests. The lack of an independent review body and the abolition of the Mental Health Act Commission further erode mechanisms for protection of patients' interests.

\section{REACTIONS TO THE MENTAL HEALTH BILL}

The Mental Health Bill has succeeded in uniting almost every pressure group, charity and professional grouping against it (the only exception is the Zito trust, which has supported it). The Royal College of Psychiatrists has described recent proposals as 'unethical, unsafe and unworkable' (Shooter, 2001) and has joined forces with other groups in the Mental Health Alliance to oppose the Mental Health Bill. It is widely perceived that the Government has no interest in any genuine process of consultation and it has ignored some of the main proposals of the Richardson Committee, such as the introduction of the concept of incapacity as a conceptual framework for legislation (Department of Health, 1999b).

\section{HISTORY OF PSYCHIATRIC LEGISLATION}

Modern psychiatric legislation combines two distinct strands of law that emerged in the 18th century in England. The first is the power of the state to incarcerate the mad, which first appeared in the 18th-century Vagrancy Laws, which empowered local magistrates to confine those considered to be 'furiously mad and dangerous'. The second strand is the concern of the state with protecting patients' interests. This was first manifested in relation to the burgeoning 18th-century 'trade in lunacy', with the passing of the Act for the Regulation of Private Madhouses 1774 (Porter, 1990). This act 
first enshrined the role of a doctor in 'certifying' madness.

These two concerns persisted throughout the 19th century. The involvement of a magistrate remained and was extended to private asylums in the Lunacy Act 1890 , as a further means of regulating this sector.

From the first decades of the 20th century the Government's agenda changed radically. This took place in a political context in which state intervention and social welfare were becoming increasingly accepted and health policy was dominated by enthusiasm for prevention and early treatment. The Macmillan Commission, which established the framework for the Mental Treatment Act 1930, was decisive in its endorsement of the medical model of mental disorder: 'There is no clear line of demarcation between mental and physical illness' it declared (Royal Commission, 1926). There was enthusiasm for abolishing the role of the magistrate in commitment proceedings despite the fact that the Royal Medico-Psychological Association did not recommend this.

However, it was not until the Mental Health Act 1959 that the principles outlined by the Macmillan Commission were fully realised. By abolishing the involvement of a magistrate and the legal proceedings that accompanied such a procedure, the act handed the responsibility for detaining the mad entirely over to professionals. Again, it is interesting that the Royal Medico-Psychological Association and the British Medical Association had not recommended this in all situations (Unsworth, 1987). The state also reduced its role of regulating psychiatric activities by abolishing the inspection system that had been operating since the 19th century. However, the act did set up a tribunal system in recognition that some mechanism for the protection of patients' interests was necessary.

The Mental Health Act 1983 reflected a renewed concern with protecting patients' interests, reflecting the influence of the civil rights movements on the 1960s and 1970s. It narrowed the definitions of certain categories of mental disorder and placed restrictions on the administration of psychiatric treatments in the absence of consent. It also reintroduced an inspectorate, the Mental Health Act Commission.

JOANNA MONCRIEFF, MBBS, MSc, Department of Psychiatry and Behavioural Sciences, University College London, Wolfson Building, 48 Riding House Street, London WIN 8AA, UK. E-mail: j.moncrieff@ucl.ac.uk

(First received 3 January 2003, accepted 9 April 2003)

\section{DISCUSSION}

This historical summary demonstrates that successive governments and governmentappointed bodies have taken the lead in promoting medical notions of mental disorder. These justified expanding possibilities for psychiatric treatment and freeing up the process of involuntary commitment from legal and therefore political scrutiny. The medical and psychiatric profession were more ambivalent about the appropriateness of the wholesale medicalisation of this process.

Recent reforms are justified on the basis of facilitating psychiatric treatment, but at the same time psychiatrists are rendered less autonomous. Having professionalised the process of dealing with the mad in 1959, the Government now appears to be clawing back power to itself, in the belief that psychiatrists are not locking enough people up (Today Programme, 1998). In contrast to other initiatives to increase the input of health service users, the reforms suggest a diminished concern with protecting patients' interests. It may be that the medicalisation of the process of psychiatric detention and care has allowed the state to devise more repressive measures than would have been tolerated in a system that was more overtly political.

\section{DECLARATION OF INTEREST}

None.

\section{APPENDIX}

\section{Features of the Mental Health Bill,} 2002

(a) Broad criteria for compulsory powers include the presence of any mental disorder (no exclusions), and compulsion is necessary for 'health, safety or protection of others' or if there is thought to be 'substantial risk' and 'it is necessary that treatment be provided' (Department of Health, 2002, p. 4). Medical treatment must be available in all cases, but this includes 'care'. (b) Non-resident orders for compulsory assessment and treatment in the community.

(c) Tribunals will make decisions about compulsory assessment and treatment in all cases lasting longer than I month. Tribunal will approve a care plan presented by the 'clinical supervisor' and will be able to retain the right to discharge a patient to itself. Tribunal may apply a treatment order when the clinical supervisor wants to continue assessment.

(d) Tribunals will only review cases on the basis of points of law.

(e) Anyone can request a Mental Health Act assessment and trusts have a duty to respond to all 'reasonable requests'.

(f) The Mental Health Act Commission is abolished.

(g) Guardianship is abolished.

(h) The right to prevent admission and request discharge of the nearest relative is abolished.

\section{REFERENCES}

Department of Health (1999a) Reform of the Mental Health Act 1983. Proposals for Consultation (Cm 4480). London: Stationery Office.

- (1999b) Report of the Expert Committee: Review of the Mental Health Act 1983. London: Stationery Office.

_ (2002) Draft Mental Health Bill. London: Stationery Office.

Department of Health/Home Office (2000) Reforming the Mental Health Act. The New Legal Framework. London: Stationery Office.

Joint Home Office \& Department of Health Working Group (1999) Managing Dangerous People with Personality Disorder. London: Stationery Office.

Porter, R. (1990) Mind Forg'd Manacles: A History of Madness in England from the Restoration to the Regency. London: Penguin Books.

Royal Commission (1926) Report of the Royal Commission on Lunacy and Mental Disorders (Cmd. 2700). London: Stationery Office.

Shooter, M. (2002) White Paper on the Reform of the Mental Health Act 1983. Letter from the Chair of the College's Public Policy Committee. London: Royal College of Psychiatrists. http: //www.rcpsych.ac.uk/college/ parliament/responses/mhbReg.htm

Sugarman, P. (2002) Detaining dangerous people with mental disorders. BMJ, 325, 659 .

Today Programme, Radio 4 (1998) See psychiatrists hit back at the Home Secretary. BMJ, 317, 1270.

Unsworth, C. (1987) The Politics of Mental Health Legislation. Oxford: Clarendon Press. 